\title{
Impact of Small Entrepreneurship on Sustainable Livelihood Assets of Rural Poor Women in Bangladesh
}

\author{
M.S. Kabir, Xuexi Hou, Rahima Akther, Jing Wang \& Lijia Wang \\ College of Economics and Management, Northwest A\&F University, Yangling 712100, China
}

Received: December 4, 2011

Accepted: January 17, 2012

Published: March 1, 2012

doi:10.5539/ijef.v4n3p265

URL: http://dx.doi.org/10.5539/ijef.v4n3p265

\begin{abstract}
The present study deals with the impact of small scale agricultural entrepreneurship on livelihood assets rural poor women and role of NGOs to developed women living of standard. The sample of the study consisted 300 women entrepreneurs those are involvement with livestock and poultry, fisheries, and vegetables entrepreneurship. Stratified Random sampling technique was used to obtained sample size. The study used the sustainable livelihood analysis framework as an analytical tool to identify ways to advance the livelihood of small entrepreneurship. Tobit and ordered probit regression estimation were used to analyze the result. Livestock and poultry entrepreneurship is significant and positively associated with financial capital, physical and social capital, vegetables entrepreneurship is significant and positively associated with natural capital and physical capital, fisheries entrepreneurship also positive and significantly associated with human capital. Role of NGOs micro credit and institutional support has great impact on women entrepreneurs living of standard. The analysis shows how entrepreneurs can achieve sustainable livelihood through access to a range of livelihood assets. Livestock and poultry entrepreneurs potentially provide higher economic returns, physical and social benefits. However, lack of resources, vulnerability and poor institutional support are identified as constraints to long term sustainability.
\end{abstract}

Keywords: Small entrepreneurship, Sustainable livelihood assets, Rural women

\section{Introduction}

A livelihood is environmentally sustainable when it maintains or enhances the local and global assets in which livelihoods depends, and has net beneficial effects on other livelihoods. A livelihood is the set of capabilities, assets and activities that furnish the means for people to meet their basic needs and support their well being. The building of livelihoods reflects and seeks to fulfill both material and experiential needs. Livelihood are not simply a localized phenomenon, but connected by environmental, economic, political and cultural process to wider national, regional and global arenas(Castro,2002).livelihood security has been interpreted in different ways by various scholars. While livelihood has been defined as an adequate flow of resources (both cash and kind) to meet the basic needs of the people, access to social institutions relating to kinship, family and neighborhoods, village and gender bias free property rights required to support and sustain a given standard of living, livelihood security has been understand to encompass ownership of access to resources and assets to offset risks, ease out shocks and meet contingencies (Chamber,1989:Redelift, 1990; Chamber and Convey,1992;long,1997;Complain,1998;Ellis,2000;Huq,2000).A good working definition of livelihoods is provided by Frank Ellis (2000:10): "the assets (natural, physical, human, financial and social capital), the activities, and the access to these (mediated by institutions and social relations) that together determine the living gained by individual or household".

In Bangladesh, women are playing an effective role in agricultural sector. Most of the housewives in rural and urban areas of Bangladesh contribute to their family income through active participation in crop, livestock, poultry, fisheries, nursery, vegetables cultivations, handicrafts as well as participating in non-farm activities. The success goes far beyond economic success. Especially in terms of women's participation in economic activities. Entrepreneurship is a dynamic function. Entrepreneurs thrive on changes in the environment that bring useful opportunities for business. Entrepreneurs always need to take different dynamic decisions. Rigid social customs and strong religious constraints are creating difficulties for women entrepreneur in operating their business.

Rural women play a very important part in the highly labor intensive production process, but within the confines of their own front yard. In agrarian and largely subsistence economy of Bangladesh, poultry, dairy, nursery, rice husking, fisheries \& handicraft enterprises play a crucial role to supply nutritious food and to generate income and employment. Poultry farming has a great potential for providing additional income to our farming community and 
educated unemployed persons, widows of rural areas through creating self employment opportunities (Ahmed and Hamid, 1991).Their participation in development activities is expected to affect their lives in personal, social and economic dimensions by increasing their access to and control over the resources. Sustainable agriculture, rural development and food security cannot be achieved through efforts that ignore or exclude more than half of the rural population- women; women constitute more than half of the agricultural labor force and are responsible for most of the household food production in low income food deficit countries. Poor rural women represent the most vulnerable group in Bangladesh they are isolated and deprived (Schuler \& Hashemi, 1995).Although women contribute considerably to rural economic activities, women gain neither recognition nor status from their work (Abdullah \& Zeidenstein. 1982).True development means the development in the three categories of a woman. These are individual, social, and economic development (Rodney, 1972).

Understanding female entrepreneurship can also have a significant impact on economic development and poverty alleviation (Kreide 2003). Female entrepreneurship has been identified as a major force for innovation and job creation (Orhan and Scott 2001). Barriers to gender entrepreneurship can have an adverse impact on a country's competitiveness, productivity, and growth potentials (Bardasi et al.2007). However, while economic growth has reduced gender disparity and improved female standards of living, especially in developing countries, such growth although important has not been synonymous with economic equality (Harrison and Bluestone 1988)

As a developing country, Bangladesh places special priority to socio-economic development. In order to accelerate the development process, the Government and Non-Government Organizations (NGOs) have undertaken massive development programs for poverty alleviation through economic activities such as livestock and poultry, fisheries, dairy, vegetables and nursery enterprises, etc. Overall objective of the study is to find out the impact of the small enterprise on livelihood assets of poor women in rural society and find out the NGOs role to developed women standard of living through sustainable livelihood approach.

\section{Sustainable Livelihoods Approach (SLA)}

Insert Figure 1 Here

A livelihood comprises the capabilities, assets and activities needed for a means of living (Scoones, 1998). A livelihood is sustainable when it can cope with and recover from stresses and shocks, and maintain or enhance its capabilities and assets, both now and in the future, while not undermining the natural resource base (DFID, 1999). According to Scoones (1998), five key indicators are important for assessing sustainable livelihoods: 1) poverty reduction, 2) well-being and capabilities, 3) livelihood adaptation, 4) vulnerability and resilience, and5) natural resource base sustainability.

The SLA is prominent in recent development programs that aim to reduce poverty and vulnerability in communities engaged in small-scale aquaculture and fisheries (Edwards et al., 2002; Neiland and Bene, 2004). It is increasingly being used by many development agencies and NGOs to achieve a better understanding of natural resource management systems (Allison and Horemans, 2006). The livelihoods approach seeks to improve rural development policy and practice by recognizing the seasonal and cyclical complexity of livelihood strategies (Carney, 2002; Allison and Ellis, 2001). It embraces a wider approach to people's livelihoods by looking beyond income generating activities in which people engage (Chambers and Conway, 1992; Farrington et al., 1999; Shankland, 2000).

The sustainable livelihoods framework helps in thinking holistically about the things that poor might be very vulnerable to, the assets and resources that help them thrive and survive, and the policies and institutions that impact on their livelihoods (DFID, 1999). Figure 1 shows the sustainable livelihoods framework and its various factors, which constrain or enhance livelihood opportunities and show how they relate to each other. The framework provides a way of thinking through the different influences (constraints and opportunities) on livelihoods, and ensuring that important factors are not neglected (Ashley and Carney, 1999). The framework shows how, in differing contexts, sustainable livelihoods are achieved through access to a range of livelihood assets which are combined in the pursuit of different livelihood strategies.

\section{Methodology}

A socioeconomic study usually requires selection of an area for collection of data in accordance with the objectives set for the study. Selection of the study area is an important step in such a study. To achieve the objectives of the present study, a preliminary survey was conducted in three entrepreneurship activities namely livestock and poultry, fish cultivation, vegetable production under the Mymensingh district to understand the broad socio-economic characteristics of the respondents.

\section{Questionnaire Interviews}

Questionnaire interviews with entrepreneurs were preceded by preparation and testing of the questionnaire, use of 
statistical procedures to determine the sample size and sampling method, and the use of enumerators to fill in questionnaires. The pre-survey activities included reconnaissance for the pilot survey, revision of survey instruments and preparation of the sampling frame. To achieve the objective of the present study the necessary data were collected from 3 sub district (9 villages) from Mymensingh district. Data were collected by the researcher himself through personal interview with the individual women.

\section{Sampling and Analysis Technique}

In a sample survey, a subset of population called sampling frame was prepared and required data were collected from the frame. Different groups of women came under the activities. Memory recall method was used to collect data before involvement and after involvement in small enterprise. Entrepreneurs respondent were selected using stratified random sampling based on entrepreneurs production systems, such as vegetable cultivation, livestock and poultry rearing, fish cultivation. Here we can categories extensive cultivation (vegetables) typically employs slightly modified versions of traditional methods called low-density and low-input systems. Semi -intensive operations (livestock and poultry) employ intermediate levels of stocking and other inputs. The intensive production (fish cultivation) system is characterized by relatively high stocking and high inputs ( Shang and Tisdell,1997; Shang et $\mathrm{al}, ;$ 1998). A total of 3000 entrepreneurs, among them 10 per cent sample were collected in each group. 100 samples were selected for each of the groups those were involvement 5-10 years with entrepreneurship activities. The sample frame thus contained 300 women respondents who were randomly selected as a sample unit.

Data were collected during July-September/2010. In order to obtain reliable data, the author first visited the study area. For collecting data, the author stayed in the selected village so that the selected women could respond at their own conveniences. At the time of interview the author asked questions systematically and explained wherever it was found necessary. The author explained the purpose of the study before interviewing and the respondents were assured that the study was purely an academic one, which wasn't likely to have any adverse affect on them. The survey method was followed in the present study. It was argued that the method was comparatively less costly, less time consuming, easier to employ and most appropriate for the enterprise working in our country.

Data from questionnaire interviews were coded and entered into a database system using Microsoft Excel software. Tobit and ordered probit estimation was used to identify the relationship between livelihood assets (financial, natural, physical, human, social) and small scale agricultural entrepreneurship and to changes in the livelihood status of the women entrepreneurs after involvement in small scale-agricultural entrepreneurship.

\section{Analytical Framework and Approach}

The five capital framework of sustainable rural livelihood is adopted here. These include natural, financial, physical, social and human capital (Carney, 1998; Davies,1996; Soussan et al.,2000). Sustainable rural livelihoods are critically linked to the enhancement of these capitals. Improvement in all these capital could be a function of changes in financial, physical, natural, social and human capital. Improvement in each of these capitals is in turn dependent on various indicators. Financial capital is dependent on income, employment and savings; physical capital is dependent on household assets, road and transport, market and health care service; natural capital dependent on water, land, temperature; social capital dependent on social institutional role (early marriage, dowry), decision ability, social prestige, solve conflict and cooperation; and human capital is dependent on health, education, training, knowledge and skills.

In the present context financial capital is measured through changes in income and savings after involvement small scale agricultural entrepreneurship activities. Physical capital is measured in terms of household possession of durable assets such as house, machinery, market, health care facilities and road transport facilities. Natural capital is measured in terms of improvements in land, sources of water and climate. Human capital is measured in terms of improvement of family health, education, knowledge and skills, indigenous knowledge and technology. Social capital is measured in terms of improvements in social prestige, decision making ability, , late marriage, cooperation between neighbors and satisfaction on own entrepreneurship, etc.

\section{Result and Discussion}

Household livelihood assets frameworks have become useful for community and family assessments and social program design for many reasons. This asset can provide a useful starting point for household livelihood analysis, as it encourages investigators to take into account all the different kinds of assets and resources that are likely to play a role in household livelihood.

\section{Financial Capital}

Financial capital includes flows as well as stock of capital and it can contribute to consumption as well as production. However, the financial resources that is available to people(whether savings, supplies of credit or 
regular earnings or pension and even in some case other assets that can converted into cash) to enable to pursue different livelihood options. Here, income and saving are the major financial resources of the entrepreneur's household. In this study we will see the relationship between financial capital and others explanatory variables which is related to entrepreneurs livelihood functions.

Insert Table 1 Here

According to the regression result, $\log$ likelihood value is 410.4926 which means we can refuse the Zero Test. $\mathrm{R}^{2}=$ maximum the likelihood function.(Table 1) shows tobit regression estimations which reveals the coefficient of dependent (financial) variables and independent variables.

From our analysis the age of the respondents is highly significant in relation to financial capital, from statistical summary the mean age of the entrepreneurs was 39 years which implies they belong to an active age, they are more capable and energetic to engage in their entrepreneurship activities. a similar distribution of age groups is also found in other studies on women entrepreneurs in Turkey (Celebi,1997). This means that younger entrepreneurs with experience tend to participate more in small scale agricultural entrepreneurship. Consequently, the amount of micro credit from NGO is positively significant associated with financial capital. It implies that the micro credit from NGO has great impact on small scale agricultural entrepreneurship profitability and that profits tend to increase amount of financial capital. One group of scholars (Rahman, 1999; Shehabuddin,1992; Mizan,1994, Pit and Khandker 1996, Todd 1996; Hashemi, Schuler, and Riley 1996, Kabeer 1998,2001) is optimistic about sustainable micro-finance programs, and the possibility of women's empowerment through micro-credit programs. In many causes, microcredit has contributed to changes in attitude about women's contribution to and role in economic and social development. Specifically, microcredit has resulted in increased recognition of women's productive role.

Earning our own money allows us to do what we want with it. It also brings us 'izzat'(honor or respect) because the money "proves" our contribution. Otherwise, we work like animals, we are never given credit for our contribution and even our own men say that we don't work. When we have our own money we are no longer mohtaj (dependent to the point of being at the other person's mercy. The word is often used for the physically disabled). (quote from a pakistani entrepreneur, in Nighat Said Khan,1984)

Additionally, formal education in school or college is significant and positively associated with financial capital. Education is very important cognitive factors for women entrepreneurship development in rural areas. Educated entrepreneurs have greater potential to discharge the entrepreneurial responsibilities effectively and efficiently. They are risk takers and have access to information regarding entrepreneurial activities. Educational attainment, a recent study found that education plays different roles in countries at different stages of economic development (Van der Sluis et al. 2005). Tobit estimations further reveals that shared labor (shared labor $=1$ other $=0$ ) is significant and positively associated with financial capital. Shared labor means entrepreneurs combine their work forces to create efficiency and also take advantage of economies of scale. In small scale agricultural entrepreneurship activities rural women share labor with family member and paid workers to run entrepreneurship venture properly, in this way they earn more profit which tends to accumulate more capital to reinvest in to entrepreneurial process.

Lack of credit (yes $=1$ no $=0$ ) is significant and negative associated with financial capital, those entrepreneurs are disadvantaged due to lack of capital which means their financial capital base is lower than those have access to sufficient credit. Those entrepreneurs lack sufficient working capital to run their entrepreneurship activities so in this regards their financial assets portfolio is low. Due to Lack of credit they can't run their entrepreneurship activities smooth, this has directly impacted on entrepreneurs programs. A deposit money facility in Bank ( $\operatorname{good}=1 \mathrm{bad}=0$ ) and collateral condition ( $\mathrm{good}=1 \mathrm{bad}=0$ ) is highly positive and significant with financial capital. Most of them respondent of entrepreneurs noticed that they have a good chance to deposit money in commercial Bank, they are very much interested to deposit in commercial bank due to high interest rate. In this way, financial capital is associated with good deposit facilities. Another very important variable is that collateral condition is more flexible in NGOs micro credit program.

Unpaid loan or credit (yes $=1$ no $=0$ ) is not significant but has negative co-efficient due to ongoing loan servicing process. It means that they pay back the credit on installment basis hence this has the effect of reducing their capital and their general cash flows. Experience on own entrepreneurship (sufficient $=1$ not sufficient $=0$ ) is also positively significant associated with financial capital. Entrepreneurship experience plays a vital role to run enterprise activities such as when, how, where to invest, buying or selling of product and saving of money, especially financial management capacity etc.Attending training on entrepreneurship is significant and positive associated with financial capital. In rural areas different NGOs those are operate micro credit program, besides they arranged training program for entrepreneurs (client) such as micro credit management which is related to financial activities.

From this table1 reveal that livestock and poultry entrepreneurship is positively significant associated financial 
capital. Vegetables entrepreneurship is not significant but positive relation with financial capital. In Bangladesh Livestock and poultry sector has got top priority in the recent years, poultry and livestock products have high demand in the markets where rural women are working as a self employed entrepreneurs. Micro credit programs that are accessible to poor households and use of sustainable approaches are essential to minimize the inherently high cost of lending.

\section{Natural Capital}

Natural capital is the term used for the natural resources stocks from which resource flows and services (e.g. nutrient cycling, erosion protection) useful for livelihoods are derived. Here we considered the sources of water, types of land, and current condition of climate are natural capital of small scale entrepreneurship. Now we will see the relationship between natural capital and entrepreneurship livelihood variables.

\section{Insert Table. 2 Here}

Table 2 present the result of the ordered probit estimation used to investigate the relationship natural capital and small scale agricultural entrepreneurships variables where dependent variables ordered score $(0,1$ and 2$)$ while 11 explanatory variables were considered in the model.

Land is the major factor of production in agrarian rural area. Access to natural capital like land, fertilizer and rain fall are crucial factors for production in small scale agricultural entrepreneurship. Here we observe that land, fertilizer and rainfall are all highly significant and positively associated with natural capital. We can also observe that the size of land, fertilizer (organic $=1$ inorganic $=0$ ), rain fall (sufficient $=1$ not sufficient $=0$ ) which means land size has direct impact on natural capital in agricultural entrepreneurship, without land we can't imagine agricultural production system. As a natural resource land has direct impact on agricultural production process but it also depend on land quality it means soil type and fertility. Organic fertilizer is pre-requisite to preserve soil fertility and productivity and sufficient rainfall tends to increase high production in agricultural sector. In rural area it is very convenient to make organic fertilizer because of available tree leafs, cow dung and by product of paddy etc. entrepreneurs prefer to use organic fertilizer than inorganic fertilizer because inorganic fertilizer price is high and it's harmful for soil fertility. Rural women can manage organic fertilizer due to availability of raw materials. If they use organic fertilizer then they can reduce cost of production and sustain soil productivity. In rural women especially they are used to apply indigenous knowledge in agricultural cropping pattern. Any technology that makes the most economic use of a country's natural resources and its relative proportions of capital, labor and skills and that furthers national and social goals (Harrison, 1983).

Rainfall has direct impact on agricultural production process but it also depends on requirement of cropping pattern. Over rainfall or insufficient rainfall has negative effects on agricultural production process. In rural area, poor farmer or agricultural crop producers depend on nature, so rural women also depend on sufficient rain. In this study area respondents women noticed that due to sufficient rain their agricultural production didn't hamper especially vegetable cultivation. Women said that whenever they need water for agricultural crop or vegetable cultivation they get it from pond or river because it's very convenient and cost is low. Due to sufficient rainfall water can preserve naturally into the pond and river. Sometimes excess rainfall also harmful for agricultural productions it creates over flooding.

Vegetation (sufficient $=1$ not sufficient $=0$ ) of the area is also highly significant and positively associated with natural capital, vegetations has vital role to maintain conducive climate, it maintains average temperature, humidity and expected rainfalls in any particular region or area. .

Another important variables is that the ground water level (availability $=1$ non-availability $=0$ ) is positive and significant relation with natural capital. Water is very important factor for production purpose especially in agrarian area without water it's impossible to sustain agricultural activities. If ground water level is above the average levels then producers have an easier task to boost their production, they can easily use normal tube well to get sufficient water this way minimizes the higher cost of production. In this model we see the vegetables entrepreneurship is significant and positively associated with natural capital because land size, fertilizer, rainfall and vegetation of the area are highly significant in the model, these kind of factors are very much related with vegetables production process, so this shows that vegetables entrepreneurs needs such kind of natural environment which not too much essentials for fisheries or livestock and poultry entrepreneurship.

Fisheries entrepreneurship is not significant but positive coefficient with natural capital; natural environment is more favor to vegetables entrepreneurs than fisheries entrepreneurs in this study area. Land ownership of women entrepreneur, Knowledge about high yielding variety, Working Experience on own entrepreneurship and Soil preservation is not significant but positively associated with natural capital. These kinds of variables have a positive 
impact on natural capital. Land ownership of women is not significant due to land tenure system or land reform system, in rural area women have no direct access to ownership of land, they use the land production purpose for the time being, most of the women entrepreneurs admit that they don't own land, but they have got opportunity for production purpose except for permanent ownership of land.High yielding variety is new terminology for rural women used for local breeding in production system either, vegetables, fisheries or other entrepreneurship activities but they don't have sufficient knowledge about HYV. Working experience has no direct impact on natural capital, and respondents working experience is not so lengthy but just average. Rural women are not well versed with soil preservation technology but they noticed that after every harvest periods they use organic fertilizer and use indigenous technology which is helpful to preserve soil fertility. Rural women are closely associated with local ecological resources and manage biodiversity on a daily basis. Agriculturally, livelihood strategies may include short-term yield enhancing strategies or longer-term soil improvement or conservation strategies (Twomlow, et al., 2002).

\section{Physical Capital}

Physical capitals comprise capital that is created by economic production process and the basic infrastructure and producer goods needed to support livelihoods. In this study, road and transport, market facilities, housing, health care facilities, and machinery equipment are considered as a physical capital of entrepreneurship activities.

Insert Table. 3 Here

Table 3 present the result of the ordered probit model used to investigate the relationship physical capital and small scale agricultural entrepreneurships variables where dependent variables ordered score $(0$ and 1$)$ while 11 explanatory variables were considered in the model. Table 3 shows, the experience on entrepreneurship, women reproductive health, sources of institutional credit and input supply availability are highly significant and positive associated with physical capital. Experience has is fundamental to operate entrepreneurship successfully, experienced entrepreneurs have know how to manage fund, how to collect input, market communication and have clear concept about physical infrastructure of entrepreneurs location. In this study we considered experienced means those are engaged 5-10 years in their own entrepreneurship activities. so we can say after involvement in agricultural entrepreneurship their physical capital has increased. Production and marketing efficiency are important determinants of entrepreneurial success. Women entrepreneurs realized that they have reproductive health care facilities (good $=1$ not good $=0$ ) after involvement in entrepreneurship activities. Health is one of the basic human rights of any nation which is related to physical infrastructure of local community. In this study area women entrepreneurs claimed that after involvement in entrepreneurship program they are well concern about reproductive and others health facilities. Now they have earning source and they are much more caring health issues. They used to seek medical attention from Government hospital, NGOs health clinic and local community clinic.

Institutional credit source is highly significant and positively associated with physical capital. The variable Sources of institutional credit $(\mathrm{NGOs}=1$ Bank $=0)$, has vital influence on women entrepreneurship activities this so because respondents are too much engaged with NGOs as opposed to Banks. Most of the NGOs provide loan without collateral and the terms are more flexible than banks', as a result it has positive impact on physical capital. NGOs microcredit programs have also, in many cases, increased mobility and strengthened networks among women who were previously confined to the home (Carr et al.,1996) borrowers build solidarity through their participation in lending circles and village organizations. There are also studies that suggest even more far-reaching social impact, including decreases in fertility rates, assumed to be linked to increased financial self-reliance (Ruhul, 1994) and more say for women in family matters, including family finances (Hashemi et al., 1996).

Input supply (availability $=1$ not available $=0$ ) is also highly and positively associated with physical capital. Input (seeds, feeds, fertilizer etc) is a major factor of production, without them the production chain would not exist. On the other hand if local infrastructure is well developed and maintained then entrepreneur's mobility is enhanced to facilitate an efficient chain of supply of the products. Availability of input supply enhances market stability in rural area. In rural areas women entrepreneurs are easy to access agricultural input if available.Land size (acre) has significant and positive coefficient with physical capital, it means that those entrepreneurs homestead and cultivable land size is big their physical capital is high. After involvement in small scale agricultural entrepreneurship women are capable to use land for production purpose whether its rent or own land. If they want to build good house they use homestead land. Dwelling facilities protect them from natural disasters and social insecurity. Road and transport facilities also depend on local people's willingness to share their land property to build necessary road that can help to transport agricultural product/input supply on time in local market Sanitation awareness (increased=1 not increased $=0$ ) is not significant but it belongs to positive coefficient with physical capital. In study area women are aware about sanitation system due to the fact that NGOs are sensitizing them about personal hygiene and health care 
matters.If women earn money and they spend on family requirements such as, food, health and education but if they get knowledge about health care or sanitation then they can prevent some disease by this way they can save money that money they spend before health care purpose. Land rent $(\mathrm{high}=1 \mathrm{low}=0)$ is negatively associated with physical capital it implies that entrepreneurs are dependent on rented land hence their physical capital is lower than those who own land. Whenever they settle their rental dues, it tends to have negative effects on others activities of entrepreneurs such as input supply, labor cost etc.

Local government support (good $=1$ not $\operatorname{good}=0$ ) and training on entrepreneurship are positively associated with physical capital but not significant. In study area most of the respondents agreed that their local government is support in favor of their entrepreneurship activities. Training on entrepreneurship not only the matter of economic activities but also taught them to learn about good health, housing, marketing and other related activities which influence to women proper functioning of own program. We can deduce from table 6 that vegetables entrepneurship is highly and positive associated with physical capital than livestock and poultry entrepreneurship. This confirms that vegetables entrepneurship has more opportunity to produce vegetable and operate their entrepreneurship activities than other entrepreneurships. Their physical infrastructural opportunity is better for vegetables entrepreneurship as compared to that livestock and poultry entrepreneurship.

\section{Human Capital}

Human capital represents skills, knowledge, good health and ability to work. Education can help to improve people's capacity to use existing assets better and create new assets and opportunities. Human capital refers to the labor available to the household: its education, skill, and health (Ellis,2000). In small scale agricultural entrepreneurship, education of entrepreneurship, knowledge, family health, experiences has been considered as a human capital.

\section{Insert Table 4 Here}

Table 4 present the result of the ordered probit model used to investigate the relationship between human capital and small scale agricultural entrepreneurships variables where dependent variables ordered score $(0,1$ and 2$)$ while 10 explanatory variables were considered in the model. Table 4 shows the training with groups, household food nutrition and sanitation, knowledge about agricultural production are highly significant and positively associated with human capital. Group training is common phenomena with NGOs activities. Agricultural entrepreneurial training is required for process, grading, manufacturing, livestock and fisheries, nursery plantation and vegetables production. Such kind of training very important for their personal development as well as entrepreneurship.

Household nutrients from foods and sanitation (very good $=2 \operatorname{good}=1$ bad $=0$ ) represent the family status in the society. After involvement in entrepreneurship activities women are offering more support to fulfill their basic needs such as nutritional food and improved personal hygiene. When entrepreneur's family affords nutritional food and good sanitations facilities, definitely the overall family health will improves. Rural Women entrepreneurs facilitate production livestock and poultry product, fish, vegetables, etc and they sell the products in market. They produce nutritious foods but they don't know which foods are more nutritious, through training programs, women entrepreneurs learnt such kind of beneficial information. Knowledge about agricultural production (high=2 medium $=1$ low $=0$ ) activities is a vital factor for agricultural entrepreneurship. In rural areas, women are often used to apply their indigenous knowledge and technology in their agricultural practices such as how to preserve seed for replanting purpose, how to make organic manure from tree leafs, garbage waste, cow dung etc. The idea is; if one woman knows this techniques then it spreads through their practical activities and interaction in productions process. Technology with an sustainable livelihood approach aims to increase productivity of all materials through the life cycle of both the programme and material (Sustainable livelihood unit,1999).

Ages of the entrepreneurs are positive significantly associated with human capital. Age has positive and negative impact on livelihood activities but it depends on which categories of age they belong; naturally children and the old are dependent more than youthful energetic working group all over the world especially if we considered it. From statistical summary we can observe that the women entrepreneurs mean age is 39 years old. It's tentatively a young age so in this age women are more capable to do more risk in entrepreneurship activities. Vigano (1993) noted that with increase in age, it is usually expected that borrowers get more stability and experience. At young age, women are energetic they can actively participate in agricultural activities either it is production process, grading process or marketing activities; additionally are highly mobile for their business purpose. Child and adult education expenses also positively and significant associated with human capital. After involvement in entrepreneurship, women are more conscious about their children and adult education so they spend more money for this purpose, and they believe that they are investing money for their children and adult education because they are aware of the benefits of education. Due to technological advancement and globalization, rural women are more interested to support their 
children and adults to get proper education in the long run get good jobs and support their families.. So women entrepreneurs are spending more money to take care of children and adults by enrolling them in good education facilities, they want to exist in society harmoniously and peacefully. By this way sustainable livelihood can be attained.

Visit to reproductive health care centre (yes $=1 \mathrm{no}=0$ ) is also significant and positively related to human capital of rural women entrepreneurship. As it's with education, good health is also a vital issue of human resource development. In rural areas of Bangladesh, women suffer health problem due social or cultural obstacles. Women are not easily allowed to visit doctors especially on reproductive health matter, one reason is uneducated women feel shy, and secondly due to religious binding they don't like to share about reproductive health issues with male doctors. But now a day's times have changed people have known about their basic human rights, literacy rates are increasing, people are more aware about their life style, dependency ratio has also decreased, especially rural women are now well organized to know about group concepts, meetings, self esteem, self respect etc. rural women entrepreneurs are more conscious about their reproductive health status. Women suffer more than men in this aspect. Women entrepreneurs often visit rural reproductive health centre or health community centre to get proper service from doctors whether the Doctor is male or female. Working experience (year) on entrepreneurship and attitude towards family planning (improved $=1$ not improved $=0$ ) are not significant but positive coefficient with human capital. In this study we see the women are engaged in agricultural entrepreneurship activities not for too long time from and statistical summary shows that's experienced mean year is 7 years. Though experience is not so much, but it has positive relation with human capital.

Attitude towards family planning is also positively coefficient with human capital. Family planning has broad meaning but in this study we considered entrepreneurs' women attitude towards small families; those families with one or two children either daughter or son, and women can understand small family's benefit suppose if they keep the family small then they can spend more time on their own entrepreneurship activities, definitely if family is big then they need to spend more money to take care of their children on needs such as food, educations expenses. Tables 4 reveal that fisheries entrepreneurship is significant and positively associated with human capital. We know that fish cultivation is harder among the three agricultural entrepreneurship; it needs skill based labor, efficient and effective entrepreneurs who are capable of doing it. Though it is a profitable business, it highly depends on entrepreneur's skills and knowledge. So we can conclude that among all entrepreneurs, fisheries entrepreneurs are more efficient than other; it means their

\section{Social Capital}

The definition of a reliable and standard measure of social capital is not an easy task. First of all, there is not a consensus on the fact of social capital being a one-dimensional (Burt 1992) or a multidimensional (Koka and Prescott 2002) concept. Moreover, social capital can be defined at different levels and for distinct units of analysis: individuals (micro level), organizations (intermediate level) of the whole society (macro level). Roughly speaking, social capital refers to social relations among persons generating productive results (Szreter 2000; Smallbone et al.2010; Ramirez et al.2010) Social networks are valuable resources since they facilitate economic activity (Nahapiet and Ghoshal 1998; Burt 1992), allow entrepreneurs to be more efficient and access privileged business opportunities (Batjargal 2003; Abreu et al.2010; Baregheh et al. 2009; Melia et al. 2010; Rubalcaba et al.2010; Toivonen and Tuominen 2009) and improve innovation (Shan et al.1994; Powell et al.1996; Ahuja 2000; Alpkan et al.2010; Bonet et al. 2010; Romero-Martinez et al.2010; Sundbo 2009; Un and Montoro-Sanchez 2010; Zhang and Duan 2010). In this study, social prestige, conflict solve capacity, cooperation between neighbors',late marriage, husband cooperation, satisfaction of own works and decision making ability of entrepreneurs are considered for social capital.

\section{Insert Table 5 Here}

Table 5 present the result of the ordered probit model used to investigate the relationship between social capital and small scale agricultural entrepreneurships variables where dependent variables ordered score $(0,1$ and 2$)$ while 11 explanatory variables were considered in the model. Table 5 shows that, contact with others entrepreneurs, leadership in NGO group meeting, participation in social gathering, water and sanitation, political consciousness and support from family are highly significant and positively associated with social capital.

Contact with others entrepreneurs (increased $=1$ not increased $=0$ ) means they have good networking system i.e if women entrepreneurs organize groups or working networks then they can overcome their obstacles easily. Rural women are very conscious about group concept due to the well known the benefit of this. Whenever any conflicts arise in the local community they can easily solve it by the rules of the NGOs group meeting activities. (Aldrich et al. 1989), too, describe women's networks as networks organized around spheres of work, family and social life. 
Similarly, Neider (1987) reports that women owned businesses are more likely to be informally structured.

Leadership (increased $=1$ not increased $=0$ ) is a very important virtue for the human society; everybody can not be a leader in group activities; but by the proper training and guidance, it can help people to achieve such kind of ability. In this research most of the women's respondents are client of micro credit institution and institution provide training to their clients. Leadership in NGOs group meeting can make entrepreneurs more self-esteem, and self respectful by this way woman feel more freedom in patriarchal society. So we can say that leadership enhanced them to take family decision, solve conflict between group member or neighbors' and increased social prestige. There is strong evidence to the effect that women are better at establishing communication and convincing others (Ufuk and Ozgen, 2001), which makes them even better at problem solving and especially in providing solutions for interpersonal problems (Eagley and Johnsn,1990).

Participation in social gathering (increased $=1$ not increased $=0$ ), women entrepreneurs and their family can be benefited by interacting with other family members, to join wedding ceremonies, rural sports programs, school or club annual programs, women cultural or local recreation activities. When women earn money in the family as a financial supporter she deserve well behave from family member and from society. After involvement in small scale agricultural entrepreneurship women feel more freedom in the family so they can enjoy social gathering like visit relatives, follow local cultural festival others social activities which is essential for human life to become more civilized and cultured.In a non-western society, Pakistan, (Shabbir and DiGregorio 1996) found that personal freedom, security and satisfaction are the primary goals of female entrepreneurs. Water and sanitation (well setup=1 not well setup $=0$ ) is crucial for human health; it also has remarkable impact on social life in rural areas. Cleanliness and personal hygiene indicates people's social status and level of civilization, in rural areas, most families don't use piped water additionally, and they do not have good sanitation facilities. In this study sample, most of class families are used to pure drinking water and good sanitations system. Respondent women noticed that after engaged with entrepreneurship activities they are more awareness about health and sanitation especially learnt from development organization when they take training or monthly group meeting. In rural area people socially considered prestigious family those are used to good sanitation and pure drinking water from own tube well.

Political consciousness and support from family (increased $=1$ not increased $=0$ ) is a vital issue now a days in rural community especially for women empowerment. In rural Bangladesh, government has established new rural power structure policy whereby any women can participate in local government political system to be elected member or chairman of the local government authority. Respondent women are more aware about their voting rights and to elect eligible person who can solve their problems such as neighbor conflict, family conflict and other social problem easily.Changes in basic needs are also positive and significantly associated with social capital. In this study we considered basic needs such as food which included rice, meat, vegetables, fish, eggs, pulses and milk; cloth; medicine and housing. After fulfilling basic requirement people can cater for additional activities. If people suffer from hunger then they will be mentally disturbed, in this way they will engage any illegal or unlawful activities. After joining own entrepreneurship activities, they are mentally stable on their own activities or enjoying self-employment opportunities because they are fulfilling family's basic requirements. It means self employment creates harmonious environment in family life as well as social life. Women get self recognition and self respect through this process. Working experience on own entrepreneurship is positive and significantly correlate with social capital. In general women entrepreneurs are engaged in entrepreneurship activities (5-10 years).In rural area women entrepreneurs aims is not only economic development but also social recognition. In developing countries' rural area like Bangladesh, women are constrained by social rule, so women entrepreneurs want to come out from that circle. Besides entrepreneurship activities, they organize group on how to make friendship, how to solve conflict with each other and how to help each other. After joining entrepreneurial activities day by day they become more experienced in social aspects or issues. Its means those women are well experienced or engaged with any development activities then their social capital will be high. Formal education and training experiences are positive coefficient but not significant with social capital. In these study women entrepreneurs are not highly educated; most of them are primary and secondary drop outs, so it is sufficient for them to get a remarkable positive impact also study shows that it has positive sign for social capital

Here we can observe that, livestock and poultry entrepreneurship is significant and positively associated with social capital. Livestock and poultry entrepreneurship is semi-intensive type of enterprise, which is an attractable activity for rural women. In the previous two models we have seen that financial and physical capital are also higher, so we can say that financial and physical capital has significant role to increase social capital for livestock and poultry entrepreneurs.

\section{Vulnerabilities}

The vulnerability concerns refer to: i) shocks, ii) adverse trends and iii) unfavorable seasonal patterns that can affect the livelihood of entrepreneurs (table 5). All these can have major impact on capital assets of households and 
individuals, and consequently on their abilities to generate incomes. It is therefore important to identify means by which negative effects can be minimized- including building greater resilience and improving overall livelihood security.

\section{Shocks}

Shocks in the form of flood or drought/ natural disaster in farming communities can destroy assets. Other natural disaster (heavy rains and cyclones) can also have significant impacts on natural resources or environmental sustainability on which an entrepreneur's livelihood heavily relies. Illness of entrepreneurs, diseases in livestock and poultry and poor harvest are all shocks and make crop or vegetable cultivation hazardous. Small entrepreneurs are especially vulnerable as shocks can force them to liquidate assets.

Insert Table 6 Here

\section{Trends}

Entrepreneurs' livelihoods can be made more or less vulnerable depending on long-term trends. Over population, environmental changes, political unrest, social conflict may aggravate the problem of meager incomes. Over populations within entrepreneurs communities can contribute to a reduction in individual access to natural resources.

\section{Seasonality}

Various types of seasonal stress emerge in small scale agricultural entrepreneurship systems. In Rural area small entrepreneurs communities with predominantly natural resource-based livelihoods are subject to seasonal cycles of stress. Seasonal employment opportunities such as trading, harvesting and marketing, and day laboring all affect livelihoods of poor people.

\section{Transforming Structures and Processes}

Transforming structures and processes are the institutions, organizations, policies and legislation that shape livelihoods. The institutions and their policies have a profound influence on access to assets (DFID, 1999). Understanding institutional processes allows the identification of barriers and opportunities to sustainable livelihoods. The study found several major transforming structures and processes that can facilitate the generation of desirable outcomes from the entrepreneurs activities (Table 7). Appropriate policies, legal instruments and enforcement can remove constraints to the development of women entrepreneurship. Government agencies, NGOs and the private sector can provide technical support to poor women entrepreneurs. Private and public institutions can catalyses and facilitate small entrepreneurship development sector. However, these institutions have not played much of a role in the development of the field in general. Thus, lack of institutional and administrative help, poor infrastructure and inadequate extension services - all have affected livelihoods of women entrepreneurs and associated groups.

Insert Table 7 Here

\section{Conclusions}

Assets or capacity building models focus attention on developing the underlying resources and capacities needed to escape poverty on a sustainable basis. The study shows the relationship between small scale agricultural entrepreneurship and livelihood assets. The study confirmed that most of the entrepreneurs have improved their socio-economic conditions through small scale entrepreneurship. A livestock and poultry entrepreneurship is significantly associated with financial, physical and social capital. Vegetables entrepreneurship has significant co-efficient with natural and physical capital, fisheries entrepreneurship also significant and positively associated with human capital. Result shows that semi intensive entrepreneurs have benefited the most results also shows the role of NGOs micro credit and training program has great impact on entrepreneurs livelihood pattern and developed living standard. Moreover, poor livelihood assets, vulnerabilities and weak transforming structures and process are identified as constraints for sustainable livelihoods of entrepreneurs and associated group. It is therefore necessary to provide institutional, organizational, and government support for sustainable small scale agricultural entrepreneurship.

\section{References}

Abdullah, T.A., \& S.A. Zeidenstein. (1982).Village Women of Bangladesh: Prospects for Change, Pergamon press, Oxford EIU,1997. Bangladesh: Vountry profile, The economist Intelligent Unit, London.

Abreu,M.,Grinevich,V., kitson,M., \& Savona,M. (2010). Policies to enhance the 'hidden innovation' in services: evidence and lessons from the UK. Service industries journal, 30(1), 99-118. http://dx.doi.org/10.1080/02642060802236160

Ahuja, G. (2000). Collaboration networks, structural holes, and innovation: a longitudinal study. Administrative science quarterly, 45, 425-457. http://dx.doi.org/10.2307/2667105 
Ahmed,S., \& M. A. Hamid. (1991). Status of Poultry Production and Development Strategy in Bangladesh, proceeding of the workshop on livestock department in Bangladesh held on July 16 to 18, 1991 at Bangladesh Livestock Research Institute, Savar, Dhaka.

Aldrich, H., Reece, P. R., \& Dubini, P. (1989). Women on the Verge of a Breakthrough: Networking among Entrepreneurs in the United States and Italy. Entrepreneurship and Regional development 1:339-56. http://dx.doi.org/10.1080/08985628900000029

Allison,E.H., \& Ellis,F. (2001). The livelihoods approach and management of small -scale fisheries.Marine policy 25,377-388. http://dx.doi.org/10.1016/S0308-597X(01)00023-9

Allison,E.H., \& Horemans, B. (2006). Putting the principles of the sustainable livelihoods approach into fisheries development policy and practice. marine policy 30,757-766

Alpkan,L.,Bulut,C., Gunday,G.,Ulusoy,G., \& Kilic, K.(2010). Organizational support for intrepreneurship and its interaction with human capital to enhance innovative performance. Management decision, 48(5), 732-755.

Ashley, C., \& Carney, D. (1999). Sustainable livelihoods: lesson from early experience. Department for International Development (DFID), London,UK.

Bardasi E, Blackden M, \& Guzman C. (2007). Gender, entrepreneurship, and competitiveness in Africa.

Baughn CC, Chua B-L., \& Neupert KE. (2006). The normative context for women's participation inentrepreneurship: a multicountry study. Entrep Theory Pract, 30(5):687-708. http://dx.doi.org/10.1111/j.1540-6520.2006.00142.x

Burt, R. (1992). Structural holes: The Social Structure of competition. Cambridge: Harvard University press.

Celebi, N. (1997). Turizm sektorundeki kucuk isyeri ve orgutlerinde kadin girisimciler[The women Entrepreneurs of the Small Enterprises and Organizations in the Tourism Sector]. Ankara: T.C.Basbakanlik kadinin status ve Sorunlari Genel Mudurlugu.

Carr, Marilyn,Martha Chen, \& Renana Jhabvala. (eds.). (1996). Speaking out: Women's economic empowerment in South Asia. London: IT Publications, 1996

Carney,D. (2002). Sustainable livelihoods approaches: progress and possibilities for changes. Department for International Development (DFID), London, UK.

Chambers, R. (1992). Rural appraisal: rapid, relaxed and participatory. IDS Discussion Paper 311, International Development Studies (IDS), Brighton, UK.

Chamber, R. (1989). Editorial Introduction:Vulnerability,Coping and Policy. IDS Bull., Vol.2, No.2, pp.1-7. http://dx.doi.org/10.1111/j.1759-5436.1989.mp20002001.x

Chamber, R., \& G.Conwey(1992).Substantial Rural Livelihoods: Practical concepts for the $21^{\text {st }}$ century, discussion paper296, institute for development studies, university of Sussex, Brighton, U.K

Complain, D. (1998). Preface: Livelihoods Issues in Root Crop Research and Development, in Sustainable Livelihood for Rural Households: Contribution from Root Crop Agriculture, Los Banos, Laguna, UPWARD, pp. $9=12$.

Department for International development. (1999). Sustainable livelihoods Guidance Sheet:Introduction.http://www.livelihoods.org/info/info_guidancesheets.html\#1.

Eagley,A.H., \& Johnson,B. (1990). Gender and leadership style: A Meta Analysis. Psychological Bulletin 108:233-56. http://dx.doi.org/10.1037/0033-2909.108.2.233

Edwards, P.,Little, D., \& Demaine, H. (2002). Rural Aquaculture. CABI International, Wallingford, Oxford, UK, $358 \mathrm{pp}$.

Ellis, F. (2000). Mixing It: Rural Livelihoods and Diversity in Developing Countries. Oxford University Press, Oxford.

Farrington,J., Carney,D., Ashley,C., \&Turton,C. (1999). Suatainable livelihoods in practice:e arly applications of concepts in rural areas. Natural Resource Perspectives, 42, Overseas Development Institute (ODI),London,UK.

Harrison B, \& Bluestone B. (1988). The great U-turn: corporate restructuring and the polarizing of America. Basic Books, New York.

Harrison, P. (1983). The Third World Tomorrow, The pilgrim Press, New York.

Hashemi, S.M., \& S.R.Schuler. (1995). Rural Credit programs and Women's Empowerment in Bangladesh. World development, 24:635-653 http://dx.doi.org/10.1016/0305-750X(95)00159-A 
Hashemi, S.M., Schuler, S. R., \& Riley, A. P. (1996). Rural Credit programs and Women's Empowerment in Bangladesh. World development 24(4): Huq,H.(2000), "People's Perception: Exploring Contestation, Counter-Development, and Rural Livelihoods; Case from Muktinagar, Bangladesh, Ph.D.Thesis, Wageningen, The Netherlands, Wageningen University.

Kabeer Naila. (2001). Conflict over Credit: Re-Evaluating the Empowerment Potential of Loans to Women in Rural Bangladesh, World Development, 29(1): Koka,B., and Prescott,J.(2002).Strategies alliances as social capital: a multidimensional view. Strategic management journal, 23, 795-816.

Kreide R. (2003). Self employment of women and welfare-state policies. Rev Int Sociol, 13(1):205-218. http://dx.doi.org/10.1080/0390670032000087069

Long, N. S. (1997). Agency and Constraint, Perceptions and Practices: A Theoretical Positions, in H.de Haan and N.Long(Eds.)(1997), Image Andrealities of Rural Life: Wageningen Perspectives on Rural Transformations, Assen, The Netherlands, Van Garcum.

Melia,M.R.,Perez, A.B., \& Dobon, S.R.(2010). The influence of innovation orientation on the internationalization of SMEs in the service sector. Service industries journal, 30(5),777-791. http://dx.doi.org/10.1080/02642060802342679

Mizan A.N. (1994). In Quest of Empowerment: The Grameen Bank Impact on Women's Power and Status, University Press Limited.

Nahapiet, J., \& Ghoshal,S. (1998). Social capital, intellectual capital and the organizational advantage. Academy of management review, 23,242-266.

Neider, L. (1987). A Preliminary Investigation of Female Entrepreneurs in Florida. Journal of Small Business Management, 25:22-9.

Orhan M, \& Scott D. (2001). Why women enter into entrepreneurship: an explanatory model. Women Manage Rev, 16(5/6):232. http://dx.doi.org/10.1108/09649420110395719

Powell,W., Koput,K., \& Smith-Doerr,L. (1996). Interorganizational collaboration and the locus of innovation: networks of learning in biotechnology. Administrative Science Quarterly, 41,116-146. http://dx.doi.org/10.2307/2393988

Pitt,M.,\& Khandker, S. (1998). The impact of group based credit programs on poor households in Bangladesh: does the gender of participant matter. Journal of political economy, 106(5),958-995. http://dx.doi.org/10.1086/250037

Rahman, A. (1999). Micro-credit Initiatives for Equitable and Sustainable Development: Who Pays? World Development, 27:(1). http://dx.doi.org/10.1016/S0305-750X(98)00105-3

Ramirez, A. R. (2010). New perspectives for the managerial entrepreneurship. International entrepreneurship and management journal, 6(2),203-219. http://dx.doi.org/10.1007/s11365-010-0146-z

Redelift, M. (1990). The Role of Agriculture in Sustainable Development, in P.Lowe, T.Marsden and whatmore(Eds.)(1990), Technological Change and the Rural Environment, London, David Fulton Publishers Ltd.,Tea Directory of HP (1997), Tea Board of India.

Romero-Martinez, A.M. Ortiz-de-Urbina-Criado,M., \& Soriano,D.R. (2010). Evaluating European Union support for innovation in Spanish small and medium enterprises. Services industries journal, 30(5),671-683. http://dx.doi.org/10.1080/02642060802253868

Roomi MA, \& Parrott G. (2008). Barriers to development and progression of women entrepreneurs in Pakistan. $J$ Entrep 17(1):59-72. http://dx.doi.org/10.1177/097135570701700105

Rrodney W. (1972). How Europe Underdeveloped Africa, London, Bogle L'ou Verture publications

Rubalcaba, L., Gallego, J., \& Hertog, P. D. (2010). The case of market and system failures in services innovation. Service industries journal.

Scoones, I. (1998). Sustainable rural livelihoods: a framework for analysis. IDS Working Paper 72, Institute of Development Studies (IDS), Brighton,UK.

Shabbir, A., \& DiGregorio, S. (1996). An Examination of the Relationship between Women's Personal Goals and Structural Factors Influencing their decisions to start a business: The case of Pakistan. Journal of Business Venturing, 11:507-29. http://dx.doi.org/10.1016/S0883-9026(96)00034-1

Shan, W.,Walter,G., \& Kogut, B. (1994). Interfirm cooperation and startup innovation in the biotechnology industry. Strategic management journal, 15, 387-394.

Shang,Y.C., \& Tisdell, C.A. (1997) Economic decision making in sustainable aquaculture development. In: 
Sustainable Aquaculture (ed.by J.E. Bardach), pp.127-148.John Wiley and Sons, Inc.,Honolulu,Hawaii,USA.

Shang,Y.C.,Leung,P., \& Ling, B. H.(1998). Comparative economic of Shrimp farming in Asia. Aquaculture 164, 183-200. http://dx.doi.org/10.1016/S0044-8486(98)00186-0

Shankland, A. (2000). Analyzing policy for sustainable livelihoods.IDS Research Report 49, Institute of Development Studies (IDS),Brighton,UK.

Smallbone,D. (2010). Government and entrepreneurship in transition economies: the case of small firms in business services in Ukraine. Service Industries Journal, 30(5), 655-670. http://dx.doi.org/10.1080/02642060802253876

Sustainable livelihood unit. (1999). Towards a technology strategy for sustainable livelihoods.DRAFT. United Nations Development programme, new York.

Sundbo, J. (2009). Innovation in the experience economy: a taxonomy of innovation organizations. Service industries journal, 29(4), 431-455. http://dx.doi.org/10.1080/02642060802283139

Szreter,S. (2000). Social capital, the economy, and education in historical perspective. Social capital:critical perspectives. Oxford: Oxford University press.

Toivonen,M., \& Tuominen,T. (2009). Emergence of innovations in services. Service industries journal, 29(7), 887-902. http://dx.doi.org/10.1080/02642060902749492

Twomlow, S., O Neill, D.Sims, B.EUis-Jones, J. \& Jafry, T. (2002) An Engineering perspective on sustainable small holder farming in developing countries. Boisystem Engineering, vol.81, no.3 pp.355-362. http://dx.doi.org/10.1006/bioe.2001.0031

Ufuk,H., \& Ozgen,O. (2001). The profile of Women Entrepreneurs:A Sample from Turkey. International Journal of Consumer Studies, 25:299=308.

Un, C.A., \& Montoro-Sanchez, A. (2010).Public funding for product, process and organizational innovation in service industries. Service Industries Journal, 30(1),133-147. http://dx.doi.org/10.1080/02642060802252035

Van der Sluis J, Van Praag M., \& Vijverberg W. (2005). Entrepreneurship selection and performance: a meta analysis of the impact of education in developing economies. World Bank Econ Rev, 19(2):225-261. http://dx.doi.org/10.1093/wber/lhi013

Vigano, Lawra. (1993). A credit scoring model for development Banks: An African Case Study. Savings and development, Vol.XVII No-4.

Zhang,J., \& Duan, Y. (2010). The impact of different types of market orientation on product innovation performance: Evidence from Chinese manufacturers. Management decision, 48(6), 849-867. http://dx.doi.org/10.1108/00251741011053433

Table 1.Tobit regression estimation of financial capital

\begin{tabular}{|c|c|c|c|}
\hline \multicolumn{2}{|c|}{ Name of the Variables } & Coefficient & Z-Statistic \\
\hline \multirow{2}{*}{\multicolumn{2}{|c|}{$\begin{array}{l}\text { constant } \\
\text { age of the respondents }\end{array}$}} & 5.157924 & $47.12942 * * *$ \\
\hline & & 0.001609 & $3.177684 * * *$ \\
\hline \multicolumn{2}{|c|}{ Amount of micro credit from NGOs } & 0.056749 & $2.255596^{* *}$ \\
\hline \multicolumn{2}{|c|}{ Formal education in school or college } & 0.002903 & $1.653416^{*}$ \\
\hline \multicolumn{2}{|c|}{ Shared labor } & 0.026031 & $2.092855^{* *}$ \\
\hline \multicolumn{2}{|c|}{ Lack of credit } & -0.037341 & $-2.430954 * *$ \\
\hline \multicolumn{2}{|c|}{ Deposit facilities in Bank } & 0.049452 & $3.058227 * * *$ \\
\hline \multicolumn{2}{|c|}{ Collateral condition } & 0.043974 & $3.175901 * * *$ \\
\hline \multicolumn{2}{|c|}{ Unpaid loan or credit } & -0.010296 & -1.128951 \\
\hline \multicolumn{2}{|c|}{ Experience on own entrepreneurship } & 0.013764 & $1.738345^{*}$ \\
\hline \multicolumn{2}{|c|}{ Vegetables entrepreneurs hip } & 0.012906 & 1.383401 \\
\hline \multicolumn{2}{|c|}{ attended training on own entrepreneurship } & 0.108657 & $2.020172 *$ \\
\hline \multicolumn{2}{|c|}{ Livestock and poultry entrepreneurship } & 0.017509 & $1.903164 *$ \\
\hline R-squared & 0.188178 & Mean dependent var & 5.516297 \\
\hline Adjusted R-squared & 0.129983 & S.D.dependent var & 0.066812 \\
\hline S.E. of regression & 0.063080 & Akaike info criterion & -2.643284 \\
\hline Sum squared resid & 1.138018 & Schwarz criterion & -2.470441 \\
\hline Log likelihood & 410.4926 & Hannan-quinn criterion & -2.574112 \\
\hline Avg.log livelihood & 1.368309 & & \\
\hline
\end{tabular}

Source field survey,2010

$* * *, * *$ and $*$ denotes significance at $1 \%, 5 \%$ and $10 \%$ respectively 
Table 2. Ordered probit regression estimation of natural capital

\begin{tabular}{|c|c|c|c|}
\hline \multicolumn{2}{|l|}{ Name of the Variables } & Coefficient & Z-Statistic \\
\hline \multicolumn{2}{|c|}{ Land ownership of women entrepreneur } & 0.171851 & 0.562044 \\
\hline \multicolumn{2}{|c|}{ Land } & 4.131993 & $9.917155^{* * *}$ \\
\hline \multicolumn{2}{|l|}{ Fertilizer } & 0.909181 & $2.693695 * * *$ \\
\hline \multicolumn{2}{|l|}{ Rain fall } & 1.227186 & $3.491950 * * *$ \\
\hline \multicolumn{2}{|c|}{ Vegetables entrepreneurship } & 0.304947 & $1.6567740^{*}$ \\
\hline \multicolumn{2}{|c|}{ Ground water level } & 0.819718 & $2.350868^{* *}$ \\
\hline \multicolumn{2}{|c|}{ Fisheries entrepreneurship } & 0.269593 & 1.383258 \\
\hline \multicolumn{2}{|c|}{ Knowledge about high yielding variety } & 0.080477 & 0.497370 \\
\hline \multicolumn{2}{|c|}{ Working Experience on own entrepreneurship } & 0.046214 & 1.040735 \\
\hline \multicolumn{2}{|c|}{ Vegetation of the area } & 1.699174 & $4.563784 * * *$ \\
\hline \multicolumn{2}{|l|}{ Soil preservation } & 0.276068 & 0.874135 \\
\hline Akaike info criterion & 1.488054 & Schwarz criterion & 1.673243 \\
\hline Log likelihood & -208.2081 & Hannan-quinn criterion & 1.562167 \\
\hline R estr.Log likelihood & -387.8192 & Avg.log likelihood & -0.694027 \\
\hline LR statistic (11 df) & 359.2222 & LR index ( Pseudo-R2) & 0.463131 \\
\hline Probability (LR stat) & 0.0000 & & \\
\hline
\end{tabular}

Source: field survey,2010

$* * *, * *$ and $*$ denotes significance at $1 \%, 5 \%$ and $10 \%$ respectively.

Table 3. Ordered probit regression estimation of physical capital

\begin{tabular}{|c|c|c|c|}
\hline \multicolumn{2}{|l|}{ Name of the Variables } & Coefficient & Z-Statistic \\
\hline \multicolumn{2}{|l|}{ Sanitation awareness } & 0.149790 & 0.861976 \\
\hline \multicolumn{2}{|l|}{ Land rent } & -0.189951 & -1.255587 \\
\hline \multicolumn{2}{|c|}{ Working experience on entrepreneurship } & 0.118093 & $2.969487^{* * *}$ \\
\hline \multicolumn{2}{|c|}{ Vegetables entrepreneurship } & 0.618493 & $3.734421 * * *$ \\
\hline \multicolumn{2}{|l|}{ Land size } & 0.646762 & $2.008908 * *$ \\
\hline \multicolumn{2}{|c|}{ Women reproductive health status } & 0.612887 & $2.884450 * * *$ \\
\hline \multicolumn{2}{|c|}{ Livestock and poultry entrepreneurship } & 0.402630 & $2.245419 * *$ \\
\hline \multicolumn{2}{|c|}{ Local government support } & 0.081322 & 0.546256 \\
\hline \multicolumn{2}{|c|}{ attended training on own entrepreneurship } & 0.023545 & 1.163434 \\
\hline \multicolumn{2}{|c|}{ Source of institutional credit } & 1.081181 & $5.311452 * * *$ \\
\hline \multicolumn{2}{|c|}{ Input supply availability } & 1.395531 & $6.113605^{* * *}$ \\
\hline Akaike info criterion & 2.145139 & Schwarz criterion & 2.330328 \\
\hline Log likelihood & -306.7708 & Hannan-quinn criterion & 2.219252 \\
\hline R estr.Log likelihood & -355.4606 & Avg.log likelihood & -1.022569 \\
\hline LR statistic (11 df) & 97.37960 & LR index ( Pseudo-R2 & 0.221802 \\
\hline Probability (LR stat) & $5.55 \mathrm{E}-16$ & & \\
\hline
\end{tabular}

Source field survey,2010

$* * *, * *$ and $*$ denotes significance at $1 \%, 5 \%$ and $10 \%$ respectively. 
Table 4. Ordered probit regression estimation of human capital

\begin{tabular}{|c|c|c|c|}
\hline \multicolumn{2}{|c|}{ Name of the Variables } & Coefficient & Z-Statistic \\
\hline \multirow{2}{*}{\multicolumn{2}{|c|}{$\begin{array}{l}\text { Training with groups in NGOs on entrepreneurship } \\
\text { Age of the entrepreneurs }\end{array}$}} & 0.279890 & $9.228943 * * *$ \\
\hline & & 0.014373 & $1.739390 *$ \\
\hline \multicolumn{2}{|c|}{ Fisheries entrepreneurship } & 0.278101 & $1.693683 *$ \\
\hline \multicolumn{2}{|c|}{ household nutrients food and sanitation } & 2.728863 & $11.55003 * * *$ \\
\hline \multicolumn{2}{|c|}{ Livestock and poultry entrepreneurship } & 0.297830 & 1.601819 \\
\hline \multirow{2}{*}{\multicolumn{2}{|c|}{$\begin{array}{l}\text { Knowledge about agricultural production } \\
\text { child and adult education }\end{array}$}} & 2.432933 & $10.61724 * * *$ \\
\hline & & 0.962650 & $1.897046^{*}$ \\
\hline \multicolumn{2}{|c|}{ Working experience on entrepreneurship } & 0.059977 & 1.221768 \\
\hline \multicolumn{2}{|c|}{ Attitude towards family planning } & 0.214277 & 1.396594 \\
\hline \multicolumn{2}{|c|}{ Visit to reproductive health care centre } & 0.683669 & $2.060312 * *$ \\
\hline Akaike info criterion & 1.432687 & Schwarz criterion & 1.605530 \\
\hline Log likelihood & -200.9030 & Hannan-quinn criterion & 1.501859 \\
\hline R estr.Log likelihood & -386.1331 & Avg.log likelihood & -0.669677 \\
\hline LR statistic (10 df) & 370.4601 & LR index ( Pseudo-R2) & 0.479705 \\
\hline Probability (LR stat) & 0.000000 & & \\
\hline
\end{tabular}

Source field survey,2010

$* * *, * *$ and $*$ denotes significance at $1 \%, 5 \%$ and $10 \%$ respectively.

Table 5. ordered probit regression estimation of social capital.

\begin{tabular}{|l|l|l|}
\hline Name of the Variables & Coefficient & Z-Statistic \\
\hline Formal Education in school or college & 0.025672 & 0.891630 \\
Training from NGOs with group on entrepreneurship & 0.016848 & 0.798090 \\
changes in basic needs & 0.171846 & $1.748134^{*}$ \\
Working experience on entrepreneurship & 0.103464 & $2.628725^{* *}$ \\
Contact with others entrepreneurs & 1.568266 & $8.806701^{* * *}$ \\
Fisheries entrepreneurship & 0.064372 & 0.369244 \\
Leadership in NGOs group meeting & 1.544197 & $7.964731^{* * *}$ \\
Participation in social gathering & 1.712960 & $9.630006^{* * *}$ \\
Livestock and poultry entrepreneurship & 0.304205 & $1.792775^{*}$ \\
water and sanitation Condition & 1.736831 & $7.460516^{* * *}$ \\
Political consciousness (voting) and support from family & 1.628800 & $6.146266^{* * *}$ \\
\hline Akaike info criterion & Schwarz criterion & 2.088152 \\
Log likelihood & Hannan-quinn criterion & 1.969671 \\
R estr.Log likelihood & Avg.log likelihood & -0.891975 \\
LR statistic (11 df) & LR index ( Pseudo-R2) & 0.316591 \\
Probability (LR stat) & & \\
\hline
\end{tabular}

Source field survey,2010

$* * *, * *$ and $*$ denotes significance at $1 \%, 5 \%$ and $10 \%$ respectively. 
Table 6. Common shocks, trends and seasonality faced by entrepreneurs'

\begin{tabular}{|l|l|l|l|}
\hline \multirow{2}{*}{ Vulnerability concerns } & \multicolumn{3}{|c|}{ Name of entrepreneurship } \\
\cline { 2 - 4 } & Livestock and poultry & fisheries & vegetables \\
\hline Shocks: & & & \\
Flood & ++ & ++ & + \\
Drought & + & + & ++ \\
Illness of entrepreneurs & + & ++ & + \\
Disease of livestock/poultry/fishery/vegetables & ++ & + & - \\
\hline Trends: & & + & \\
Over population & + & + & + \\
Political unrest & ++ & + & - \\
Local government politics & + & + & + \\
Resource trends through social conflicts & + & ++ & - \\
Environmental change & + & + & - \\
\hline Seasonality: & & + & \\
Of production & ++ & ++ \\
Of prices of product & ++ & + & + \\
Of employment opportunities & + & + & + \\
Shortage of feed supply & + & + & - \\
\hline
\end{tabular}

,,++++++ : mild to strong impacts

-: no impact

Table 7. Components of transforming structures and processes to the development small scale agricultural entrepreneurship.

\begin{tabular}{|l|ll|}
\hline components & Example \\
\hline Policies & i. & Pertinent government policies(technical support) \\
& ii. & Rules and regulations for sustainable agricultural entrepreneurship \\
& iii. & Environmental protection (control pollution and diseases) \\
\hline Institutions & i. & Roles of government agencies, research institutions and NGOs \\
& ii. & Roles of private institutions.( feed factory, seed suppliers) \\
& iii. & Public and private partnership (research initiatives, entrepreneurship development, agricultural product marketing) \\
\hline Service and facilities & i. & Agricultural extension services and training facilities \\
& ii. & Credit facilities to rural poor women \\
& iii. & Infrastructure development (communication, road ,markets) \\
\hline Social issues & i. & Conflict prevention( land reform, social stability, dowry, early marriage, women rights) \\
& ii. & Minimize power relation (patron-client, poor and rich entrepreneurs, money lenders) \\
\hline Labour market & i. & On-farm employment opportunities through agricultural production process and build agri-based industry in rural area. \\
& ii. & Off-farm employment opportunities ( feed industries, agricultural product processing and marketing. \\
\hline
\end{tabular}

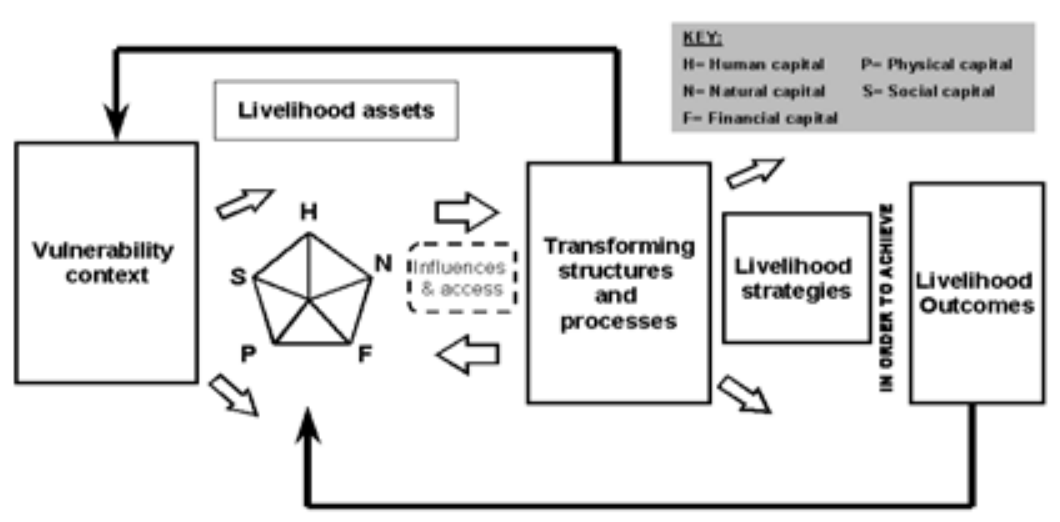

Figure1. Sustainable livelihood Approach 